University of Wollongong

Research Online

Faculty of Law, Humanities and the Arts Papers (Archive)

Faculty of Arts, Social Sciences \& Humanities

$1-1-2018$

Firm Performance and Market Behaviour: The Scholarship of David Merrett

Simon Ville

University of Wollongong, sville@uow.edu.au

Follow this and additional works at: https://ro.uow.edu.au/lhapapers

Part of the Arts and Humanities Commons, and the Law Commons

Research Online is the open access institutional repository for the University of Wollongong. For further information contact the UOW Library: research-pubs@uow.edu.au 


\title{
Firm Performance and Market Behaviour: The Scholarship of David Merrett
}

\author{
Abstract \\ David Merrett's academic career as an economic historian began in the 1960s as a teaching fellow and \\ master of economics candidate at Monash University. The social sciences were experiencing their \\ postwar expansion (Macintyre, 2010); economic history was as an important component of this growth \\ with an array of subjects offered, new appointments made, and a recently established (1967) specialist \\ journal, the Australian Economic History Review. This was an exciting time to commence a career as an \\ economic historian in Australia. \\ Disciplines \\ Arts and Humanities I Law \\ Publication Details \\ Ville, S. (2018). Firm Performance and Market Behaviour: The Scholarship of David Merrett. Australian \\ Economic History Review: an Asia-Pacific journal of economic, business and social history, 58 (3), \\ 222-232.
}

This journal article is available at Research Online: https://ro.uow.edu.au/lhapapers/3730 
Firm Performance and Market Behaviour: the Scholarship of David Merrett

\author{
Simon Ville \\ University of Wollongong
}

JEL categories N01; N27; N87

David Merrett's academic career as an economic historian began in the 1960s as a teaching fellow and master of economics candidate at Monash University. The social sciences were experiencing their postwar expansion (Macintyre 2010); economic history was as an important component of this growth with an array of subjects offered, new appointments made, and a recently established (1967) specialist journal, the Australian Economic History Review. ${ }^{1}$ This was an exciting time to commence a career as an economic historian in Australia.

The enormous intellectual contribution of Noel Butlin, Professor of economic history at ANU, dominated the field, and his personality towered above its community of scholars. Butlin brought the world of Simon Kuznets and his national income accounting framework to Australia and, in two major works, provided much of the empirical basis for describing the growth of the Australian economy for nearly a century after 1860 (Butlin 1962; Butlin 1964). Estimating and analysing its macroeconomic aggregates became the methodological focus of the work of his many followers. ${ }^{2}$

Some of David's early work lay in this tradition, particularly his master of economics thesis on economic fluctuations in NSW and Victoria immediately before World War

\footnotetext{
${ }^{1}$ Its initial forerunner, the Bulletin of the Business Archives Council of Australia, was first published in 1956, changing its name to Business Archives and History in 1962.

2 Especially Ian McLean, Gus Sinclair, Colin Forster, Alan Barnard, Susan Bambrick, Alan Hall, and Jack Dowie.
} 
One (Merrett 1969), suggested by Butlin, ${ }^{3}$ along with a chapter on twentieth-century urbanisation (Merrett 1978). However, other thinkers also shaped David's scholarly direction. Gus Sinclair, his thesis supervisor at Monash, while a proponent of Butlin's methodology, diverged from Butlin in some of his interpretations. In particular, Sinclair did not share Butlin's disregard of the role of natural resources industries in Australian development. John McCarty and Boris Schedvin were the two other colossi of the Melbourne economic history scene by the 1970s who placed greater emphasis than Butlin on external influences and the role of policy and organisations in the character of Australian economic development. ${ }^{4}$

These influences revealed in David a more critical approach to aggregate models than was to be found in the work of many of Butlin's followers. Several articles, jointly authored with Tony Dingle, questioned some of Butlin's generalisations about the impact of the 1890 s economic crisis. In particular, they bravely concluded in 1972, 'it is difficult to support Butlin's contention that the tenancy levels in Melbourne increased substantially as a result of the depression' (Dingle and Merrett 1972, p. 35). Using the rate books, property by property, they showed that the impact of the depression on home ownership was a good deal more complex and reflected differing impacts of the downturn from suburb to suburb. Later, in a related study, Merrett showed that, in spite of the expansion in the number and range of financial institutions in Australia from the mid-nineteenth century, they funded less than half of the cost of the housing stock well into the twentieth century (Merrett 2000a). Also with Dingle, David ventured into comparative economic history by editing a volume on the economic development of Australia and Argentina (Dingle and Merrett 1985). These endeavours may have

\footnotetext{
3 'Interview of David Merrett' by Claire Wright. 2/3/2015.

${ }^{4}$ The intellectual and locational influences on the economic history community of the 1960s and 1970s are addressed in detail in Wright (2017), chs 6- 9.
} 
portended David's intellectual schism with the 'House of Butlin' towards seeking a clearer understanding of the microeconomic foundations of Australian development in the twentieth century. External shocks, cyclical instability in markets, and shifts in relative prices required alternative and more fine-grained methods of analysis.

Understanding why markets succeed or fail and the role of firms and governments in shaping these outcomes has proved to be the location of David's abiding and insightful contributions to the field. These are the vital economic building blocks on which broad aggregate assessments of national and comparative economic development rest. Adopting an historical lens, David's work has challenged some of the reductionist assumptions about the behaviour of firms and markets often found in macroeconomic models. His work, above any economic historian in Australia, has shown how complex markets can be - many involve unique products like wool, and they do not clear easily, converge to best practice, or adopt common rates of progress. David's work took these challenges into the business and policy environment as well as economics, showing how the behaviour of large-scale enterprise, colluding smaller firms, and the often mercurial decisions of government all helped to shape distinctive patterns of development.

One of David's earliest forays into the functioning of markets was a study of the Victorian government's licensing of the sale of alcohol from 1906. Ostensibly designed to address the negative externalities of alcohol consumption, he showed that the continuation of this 'costly and ineffectual' policy over a long period reflected the benefits of a share in the monopoly rents accruing to the trade, the courts, and government (Merrett 1979). ${ }^{5}$ The, often unhappy, interaction between policy and industrial development was also taken up in a study that showed the weak relationship

\footnotetext{
5 'Interview' Merrett indicates that the idea for this paper arose from a conversation about some of the negative consequences of licensing.
} 
between defence policy and domestic manufacturing after World War II (Merrett and Schedvin 1981).

However, David soon turned to examining the finance sector from many perspectives the capital market, banking, crises, international banking, and corporate history - which was to be the focus of much of his scholarly output throughout the 1980s and 1990s. His first major contribution was to write a history of the ANZ bank over the previous fifty years, building on Syd Butlin's study of its earlier years (Merrett 1985). The resulting work reflected his interests in policy but, assisted by advice from Keith Trace and Boris Schedvin, it also evolved into an insightful corporate study. It addressed a range of developments in corporate strategy and organisational structure before these Chandlerian approaches became commonplace in the history of big business. Merrett examined the growth of profit planning, area banking, management accounting, improved disclosure, professional career planning, management training, and international expansion. The key strategic decision, the change of domicile from Britain to Australia in 1977, was examined in some detail, although its full ramifications would have been impossible to judge less than a decade after the event.

Merrett's strengthening command of the interaction between government regulation and corporate strategy informed his important revisionist interpretations of the banking crisis of the 1890s. He argued that illiquidity and corruption was only part of the story, also important were weaknesses in organisational design, excessive risk concentration, and a mismatch in the maturity profile of assets and liabilities. Further, an expansion in the banking industry and primitive accounting conventions made the detection of poor prudential behaviour difficult until a very late stage of the impending 
crisis (Merrett 1989).6 Merrett has maintained his interests in the finance sector, penning two sequential authoritative overviews of the development of the Australian capital market in the century from 1890 (Merrett 1997; Merrett 1998). A more research oriented paper with Ville examined the development of the equity market in the interwar period through analysing an extensive database of new issues (Merrett and Ville 2009). Finally, he returned to the 1890s crisis in 2013 to explain how changes to company legislation provided a soft landing from the banking crisis by facilitating schemes of reconstruction (Merrett 2013).

Following on closely from this work, and influenced by the large emerging body of research on multinationals by business historian Geoff Jones, Merrett began analysing international banking - both Australian firms overseas and foreign enterprise in Australia. Of particular importance was his identification of ('largely ignored') correspondent banking, rather than multinational banking, as the principal means of transferring funds across borders. Put simply, correspondent banking involved banks providing services to their overseas customers through the agency of a correspondent bank located in that country (Merrett 1995, p. 70).

The ideas and broad themes developed in these studies of money and banking helped to set many of the future agendas for David's research, particularly the study of incoming and outgoing multinationals, the origins and growth of big business in Australia, and the functioning of Australian markets such as wool and, more recently, food products.

The changing university environment in Australia in the 1990s, particularly degree structures and patterns of university environment, also affected the research plans of David and indeed many scholars of economic history. Falling revenue per student

\footnotetext{
${ }^{6}$ Relatedly, see Merrett (1993).
} 
combined with a more commercial orientation of universities contributed to the closure of small departments of economic history and exerted pressure to deliver business degrees with a more contemporary and vocational orientation. The Melbourne department responded by changing its focus towards the study of Asia particularly economic development and international business. Led by Stephen Nicholas and leveraging the key theoretical concept of transactions costs, several members of the department refocussed their research towards the study of contemporary Asian multinationals in Australia. In a series of co-authored articles, particularly with Nicholas, William Purcell, and Greg Whitwell, David's work focussed on understanding the investment decisions and entry modes of Japanese firms, across manufacturing, finance, and tourism, entering Australia in the 1990s (Nicholas et al. 1997; Purcell et al. 1999).

At the same time, David's historical scholarship continued to pioneer the study of outgoing Australian multinationals with papers on banks investing in Asia, and beer and wine firms in the United Kingdom (Merrett 1991; Merrett \& Whitwell 1994). These individual cases culminated in an epochal paper in Business History in 2002, which analysed the belated expansion of Australian firms overseas before the 1980s and asked multiple questions, 'Why so few, why those, and why there'. The answers to these questions lay in a vicious cocktail of country and policy impediments - Australia lacked the large concentrated population necessary to develop competitive manufacturing and services firms locally, while an immature capital market and protectionist policies made matters worse. Firms stayed at home, largely protected by tariffs from foreign competition and able to collude with each other at the expense of the consumer. Microeconomic reform, especially tariff reductions and competition policy, began to change the corporate landscape by the 1980s. 
These themes were broadened and generalised into an edited book five years later addressing the internationalising strategies of industries and firms from a small economy, Australia, in which David and Howard Dick coordinated the interests of a range of scholars from the international business discipline at Melbourne. In a jocularly subtitled chapter, 'Do you come from a land downunder?', Merrett (2007b) extended his Business History paper to examine outgoing Australian multinationals beyond 1980. The rapid growth of outward foreign direct investment since then can be explained by several motives, particularly access to overseas markets, microeconomic reform at home, the quality of human capital in the firm, and legacy issues such as experiential learning. The mixed results of these internationalising firms continue to be a source of contemporary discussion and debate. David contributed several case studies examining competitive advantages that enabled Australian firms to go global in the face of the country specific disadvantages of their home economy. For 'Aspro' (aspirin) and 'Kiwi' (shoe polish), it was the rapid establishment of global brands in response to opportunities opening in World War One that set them on a course of eighty-year success stories (Merrett 2007a). Macquarie Bank's success was attributed to niche opportunities in global investment banking driven by 'entrepreneurship, innovation, and focused discipline' (Merrett and Newitt 2007, p. 327).

In order to better understand the challenges facing Australian firms internationalising, a careful analysis of the development of big business in Australia was necessary. The national literature in Australia had failed to keep up with the exciting developments in business history overseas, especially the magisterial contributions of Alfred Chandler and his circle at the Harvard Business School in the 1960s to 1990s. The brilliant storytelling business histories of Geoffrey Blainey provided a limited basis for a deeper theoretical understanding of how Australian firms grew and with what competitive 
advantages this had equipped them. In 2000, Merrett edited a special issue of Business History which brought together a group of scholars who were seeking to provide new perspectives on Australian business history. The papers addressed the behaviour and performance of a series of Australian firms using theories and methods new to business history in Australia and not so common overseas. These included collusion theory, transactions costs, firm competencies, and principal agent theory.

In the issue's lead article, Merrett co-authored with Ville an overall analysis of the growth of big business in twentieth-century Australia (Ville and Merrett 2000). It used Alfred Chandler's methodology and precepts to identify the largest one hundred firms in Australia across a set of four benchmark years - 1910, 1930, 1952, and 1964. It revealed some interesting findings, not least that many enduring leaders came from the resource industries and that foreign multinationals ranked highly in manufacturing. Overall, Australian big business was more dominant in its domestic economy than was the case for a series of leading nations including USA, Britain, and Germany. Nonetheless, the largest firms were minnows compared with their counterparts in these other more sizeable economies. This raised questions as to whether these leading firms faced, on the one hand, limited competition domestically and, on the other, an insufficient market from which to build scale economies. On top of this, the persistence of family operated firms suggested that the advance to the Chandlerian firm through investments in production and management was slow to occur in Australia. As Merrett noted, however, in the introduction to the special issue, 'Ville and Merrett have barely scratched the surface of the issues that have emerged from the debates surrounding the Chandler theses' (Merrett 2000b). 
The groundwork paper was developed four years later into an important monograph with Ville and Grant Fleming, The Big End of Town. This took the story of large scale enterprise to the end of the twentieth century and provided a much more detailed investigation of the growth directions and methods of Australian corporate leaders and the development of their organisational structures (Fleming, et al. 2004). In the same year, Merrett published a business biography of William Lionel Buckland, which reminded us that there is no single pathway or preferred structure for the successful business enterprise (Merrett 2004). Buckland's empire, mostly a collection of private companies, epitomised the entrepreneurial, rather than the managerial, enterprise. He was the 'antithesis of a Chief Executive who stood above the detail' and summarised his own philosophy as, 'there can only be one captain ... and he must be on the bridge' (Merrett 2004, p. 76).

The Big End of Town expanded on the Chandlerian emphasis on size by also looking at the longevity of leading firms, identifying six which remained in the top 100 list throughout the twentieth century. Subsequent papers investigated fluctuations in business profitability over time and between sectors (Ville and Merrett, 2006a). In the process, the important conclusion was reached that domestic profit opportunities drove the expansion of the manufacturing sector alongside the primacy normally attributed to tariff policy in structural change (Merrett and Ville 2011). The various threads of this joint work with Ville on corporate Australia were in many ways brought together in an article in 2018 (Panza, Ville, Merrett 2018). Accompanied by Laura Panza, they evaluated the role of size, age, and profitability in the survival rates of firms to reach the unexpected conclusion that, for most sectors, it was age and profitability that mattered not size. 
It was perhaps appropriate, therefore, that David had already begun to move away from studying the strategies of big business to analyse interaction among groups of firms and how their behaviour helps to shape markets. This decision may have been triggered by the fortuitous discovery of an old copy of the rulebook of the Melbourne Woolbrokers Association in a second hand bookshop and the ongoing work of Ville on the Australasian wool trade and its key players. Over the last decade, Merrett and Ville have co-authored five articles and a book chapter on the market for wool; testing and applying concepts from institutional theory, social capital, and anthropomorphism. Wool is a commodity whose heterogeneous and tactile qualities have been important factors in the distinctive nature of its marketing, and the sale of which remains today predominantly through open cry auctions. Cooperation and collusion among firms helped to shape the performance of wool markets for better or worse. Collusive behaviour among a small group of large woolbrokers led to limit pricing (Merrett and Ville 2012). On the other hand, cooperation through industry associations, fostered the development of a highly efficient centralised auction system in Australia amongst otherwise competing firms (Merrett, et al. 2008; Ville and Merrett 2006b). The pattern of cooperative behaviour was highly contingent with the rich seams of social capital developed among the Melbourne brokers standing in contrast to the conflict and disagreement that often prevailed between the Sydney firms (Merrett and Ville 2013). In a further paper, Merrett and Ville challenged the common assumption among economists that market practices converge towards a single best form. Comparing the different methods of selling raw wool among the big five producers - Australia, New Zealand, South Africa, Argentina, and Uruguay - they identified a lack of isomorphism, concluding, 'our contribution reminds us of the geographical, historical, and cultural differences that shape the distinctive development paths of each nation in the face of 
apparently immutable forces of convergence' (Merrett and Ville 2015, p. 253). Finally, the oscillation between auctions and wartime government intervention in wool markets lay behind the debates and socio-political manoeuvring for a peacetime reserve price scheme. Its belated arrival in 1971 proved to be a disaster for the industry from which it is only now recovering (Ville and Merrett 2016).

More recently, Merrett has begun an examination of the grocery and horticultural trades that analyses the complex set of factors that bear on the functioning of these markets. These include product measurement and perishability, distance, downstream market power, and the exercise of regulation through state intervention and industry codes of conduct (Merrett 2017).

David's immense contribution to Australian economic history can be evidenced through data relating to the Australian Economic History Review. He has published more pages of research (252) than any other author and over a longer period of time (46 years). He is the journal's third most cited author (116), and one of his papers ranks (13) among the journal's most highly cited works (Seltzer 2018). However, as we know well, published output and its referencing by other authors is only one of many ways of assessing the contribution and influence of a scholar. His suggestions and advice are valued very highly by many leading international scholars. Often it is what is invisible from a scholar's curriculum vitae, tacit achievements, which are as important as those evident in the public domain. Professor Geoff Jones, Isidor Straus Professor of business history at Harvard Business School, has repeatedly acknowledged Merrett's advice in the preface of his books. In his 2000 study of British multinationals, Jones wrote, 'David Merrett, an outstanding scholar who combines exceptional historical scholarship with a 
deep understanding of theory, told me what I wanted to say, following a tradition established in two previous books' (Jones 2000, p. v).

In the introduction to the 2000 special issue of Business History, Merrett wrote, 'these essays represent a new wave of Australian business history, it is a moot point whether this style of scholarship will redefine the genre' (Merrett 2000b, p. 10). Nearly two decades later, it would be reasonable to conclude that Australian business history has become more theoretically informed, methodologically diverse, and better engaged with international scholarship. ${ }^{7}$ David Merrett has been an important, enduring pioneer and thought leader in this process, particularly through his articulation of the forces that connect firm performance with market behaviour.

David is relatively unusual in his ability to understand and integrate thinking about markets, normally the domain of the economic historian, with an analysis of enterprises, work mostly associated with business historians. His interdisciplinary approach is also reflected in his willingness to combine theorising from economics and management with the historian's reference to archival evidence and the use of narrative.

It is appropriate, therefore, that the contributors to this volume, all with scholarly connections to David, come from a variety of disciplinary backgrounds.

This special issue, dedicated to David Merrett, includes five papers written by former students, colleagues, and collaborators that address topics related to David's scholarly contributions, in some cases engaging directly with his work.

Geoff Jones has drawn extensively on the Creating Emerging Markets (CEM) oral history database to analyse five types of political risks firms encountered in South Asia and

\footnotetext{
${ }^{7}$ Some important examples include: Boyce 2001; Keneley 2009; Seltzer and Sammartino 2009; Shanahan, and Round 2009; Van der Eng 2018.
} 
Latin America since 1970 and how they responded. This innovative paper uses Nvivo software to analyse the details of 71 interviews that span across nine countries and relate to domestic firms, contrasting with the international business focus of most prior studies of political risk.

Stuart Macintyre's contribution uses as its starting point Merrett's work on the relationship between, and relative sizes of, the public and private housing sectors and on the sources of housing finance (Dingle and Merrett 1972; Merrett 2000a). Macintyre provides an account of the failure of public housing policy in the 1940 s, specifically the Commonwealth Housing Commission, 1943-9. The cornerstones of the policy, in the shadow of the deprivations of war, were the universal right to adequate housing, social and physical urban planning, and expanded public housing provision. None of these aims was achieved. Macintyre explains how this reforming policy fell out of favour in the changed political circumstances after the war. Instead, it was the private sector owner-occupiers that dominated the postwar housing expansion.

Grant Fleming looks at an alternative form of financial intermediary, the leveraged buyout (LBO), and focusses on its growth and its influence on corporate restructuring in Australia, Japan, and South Korea, 1980-2010. Three waves of activity are identified in this period variously driven by information asymmetries, favourable policy shifts, and the availability of cheap credit. As a result, regional LBOs have moved from niche financial intermediaries to mainstream players in the financial and corporate control markets and have integrated with international capital markets in this field.

Monica Keneley's study of organisational response among leading insurance companies connects with Merrett's scholarship on the finance industry, large scale enterprise in Australia, and the impact of corporate longevity (for example: Fleming, et al. 2004; 
Panza, et al. 2018). Using a dynamic capabilities framework, she explains the manner in which leading Australian mutual life insurers, including AMP, National Mutual Life, and Colonial Life, struggled to adapt their organisations to major external changes, particularly the deregulation policies of the 1980s. Size and administrative legacies are presented as constraints on their responsiveness to altered operating conditions.

Finally, Andrew Seltzer focusses on a topic, Australian banking, in which he and Merrett have previously co-authored (Merrett and Seltzer 2000; Seltzer and Merrett 2000). Merrett $(1985 ; 1995)$ argued that branch banking did not necessarily provide better outcomes for banks because the benefits of geographic diversification were more than offset by the consequential choice to invest in higher risk assets and a reduction in prudential standards. Seltzer shows that branch banks were more likely to suspend during the 1893 crisis than were unit banks. Further, he argues that the benefits of branching had more to do with geographic specialisation than diversification. 
References

Boyce G. H. (2001) Co-operative Structures in Global Business: Communicating, Transferring Knowledge, and Learning across the Corporate Frontier (London: Routledge).

Butlin, N. G. (1962) Australian Domestic Product, Investment and Foreign Borrowing 1861 -1938/9 (London: Cambridge University Press).

Butlin, N. G. (1964) Investment in Australian Economic Development, 1861 - 1900 (London: Cambridge University Press).

Dingle, A. E. and Merrett, D. T. (1972) Home owners and tenants in Melbourne, 18911911. Australian Economic History Review, 12, 1: 21-35.

Dingle, A. E. and Merrett, D. T. (1985) Argentina and Australia: Essays in Comparative Economic Development (Clayton, VIC: Economic History Society of Australia and New Zealand).

Fleming, G., Merrett, D., and Ville, S. (2004) The Big End of Town: Big Business and Corporate Leadership in Australia (Cambridge, Cambridge University Press).

Jones, G. (2000) Merchants to Multinationals: British Trading Companies in the Nineteenth and Twentieth Centuries (New York: Oxford University Press).

Keneley, M. (2009) Organizational capabilities and the role of routines in the emergence of a modern life insurer: the story of the AMP. Business History, 51, 2: 248-67.

Macintyre, S. (2010) The Poor Relation. A History of Social Sciences in Australia (Melbourne: Melbourne University Press).

Merrett, D. T. (1969) Economic fluctuations in Victoria and New South Wales, 19071914. Masters thesis, Monash University.

Merrett, D. T. (1978) Australian capital cities in the twentieth century. In J. W. McCarty and C. B. Schedvin, eds. Australian Capital Cities: Historical Essays (Sydney: Sydney University Press), pp. 171-98.

Merrett, D. T. (1979) The Victorian Licensing Court 1906-68: a study of role and impact. Australian Economic History Review, 19, 2: 123-50.

Merrett, D. T. (1985) ANZ Bank: a History of the Australia and New Zealand Banking Group Limited and its Constituents (Sydney: Allen \& Unwin).

Merrett, D. T. (1989) Australian banking practice and the crisis of 1893. Australian Economic History Review, 29, 1: 60-85.

Merrett, D. T. (1991) Paradise lost? British banks in Australia. In G. Jones, ed. Multinational and International Banking (Aldershot: Edward Elgar), pp. 305-27;

Merrett, D. T. (1993) Preventing bank failure: could the Commercial Bank of Australia have been saved by its peers in 1893? Victorian Historical Journal, 64, 2: 122-42.

Merrett, D. T. (1995) Global reach by Australian banks: correspondent banking networks, 1830-1960. Business History, 37, 3: 70-88. 
Merrett, D. T. (1997) Capital markets and capital formation in Australia, 1890-1945. Australian Economic History Review, 37, 3: 181-201.

Merrett, D. T. (1998) Capital markets and capital formation in Australia, 1945-1990. Australian Economic History Review, 38, 2: 135-54.

Merrett, D. T. (2000a) Paying for it all. In P. Troy, ed. A History of European Housing in Australia (Cambridge: Cambridge University Press), pp. 237-53.

Merrett, D. T. (2000b) Business institutions and behaviour in Australia: a new perspective. Business History, 42, 3: 1-12.

Merrett, D. T. (2004) William L Buckland (Melbourne: The William Buckland Foundation).

Merrett, D. T. (2007a) 'Aspro' and 'Kiwi'. In H. Dick and D. T. Merrett, eds. The Internalisation Strategies of Small-Country Firms. The Australian Experience of Globalisation (Cheltenham: Edward Elgar), pp. 246-57.

Merrett, D. T. (2007b) Australian multinationals in historical perspective: 'Do you come from a land down under?'. In H. Dick and D. T. Merrett, eds. The Internalisation Strategies of Small-Country Firms. The Australian Experience of Globalisation (Cheltenham: Edward Elgar), pp.18-36

Merrett, D. T. (2013) The Australian bank crashes of the 1890s revisited. Business History Review, 87, 3: 407-29.

Merrett, D. T. (2017) Market failure in the Australian horticulture supply chain: causes and responses 1913-2015, Paper presented to the Asia-Pacific Economic and Business History Conference, RMIT, Melbourne.

Merrett, D. T., Morgan, S. L. and Ville, S. (2008) Industry associations as facilitators of social capital: the establishment and early operations of the Melbourne Woolbrokers' Association. Business History, 50, 6: 781-94.

Merrett, D. T. and Newitt, S. (2007) Macquarie Bank. In H. Dick and D. T. Merrett, eds. The Internalisation Strategies of Small-Country Firms. The Australian Experience of Globalisation (Cheltenham: Edward Elgar), pp. 319-28.

Merrett, D. T. and Schedvin, C. B. (1981) Australia: Dependence at the periphery. In B. F. Cooling ed. War, Business, and World Military-Industrial Complexes (New York: Kennikat Press Corp), pp. 120-45.

Merrett, D. T. and Seltzer, A. J. (2000) The nature of bank work and worker monitoring: a study of the Union Bank of Australia in the 1920s. Business History, 42, 3: 133-152.

Merrett, D. T. and Ville, S. (2009) Financing growth: new issues by Australian firms, 1920-1939. Business History Review, 83: 563-89.

Merrett, D. T. and Ville, S. (2011) Tariffs, subsidies and profits: a re-appraisal of structural change in Australia 1901-1939. Australian Economic History Review, 51, 2: 4670 .

Merrett, D. T. and Ville, S. (2012) Industry associations and non-competitive behaviour in Australian wool marketing: evidence from the Melbourne Woolbrokers' Association, 1890-1939. Business History, 54, 4: 510-28. 
Merrett and Ville, S. (2013) Institution building and variation in the formation of the Australian wool market. Australian Economic History Review, 53, 2: 146-66.

Merrett, D. T. and Ville, S. (2015) Accounting for non-convergence in global wool marketing before 1939. Business History Review, 89, 2: 229-54.

Merrett, D. T. and Whitwell, G. (1994) The Empire strikes back: marketing Australian beer and wine in the United Kingdom. In G. Jones and N. Morgan, eds. Adding Value: Brands and Marketing in Food and Drink (London: Routledge), pp.162-88

Purcell, W., Nicholas, S., Merrett, D. T. and Whitwell, G. (1999) The transfer of human resource and management practice by Japanese multinationals to Australia: Do industry, size and experience matter? International Journal of Human Resource Management, 10, 1: 72-88.

Nicholas, S., Merrett, D.T., Whitwell, G., and Purcell, W. (1997) Japanese multinationals in Australia in the 1990s: manufacturing, financial services and tourism, Oteman Bulletin for Australian Studies, 22, 12: 17-56.

Panza, L., Ville, S., and Merrett, D. T. (2018) Size, profitability and survivorship: the performance of large scale enterprise in Australia. Business History, 60, 2: 157-77.

Seltzer, A. (2018) Publication trends and future challenges for the AEHR: a bibliometric analysis. Australian Economic History Review 58, 3 (2018): 338-61.

Seltzer, A. and Merrett, D. T. (2000) Personnel practices at the Union Bank of Australia: panel evidence from the 1887-1900 entry cohorts. Journal of Labor Economics 18, 4: 573-613.

Seltzer, A. and Sammartino, A. (2009) A new look at Australian labour contracts: evidence from inside large firms. Australian Economic History Review, 49, 2: 107-37.

Shanahan, M. P. and Round, D. K. (2009) Serious cartel conduct, criminalisation and evidentiary standards: lessons from the Coal Vend case of 1911 in Australia. Business History, 51, 6: 875-906.

Van der Eng, P. (2018) Turning adversity into opportunity: Philips in Australia, 19451980, Enterprise \& Society, 19, 1: 179-207.

Ville, S. and Merrett, D. T. (2000) The development of large scale enterprise in Australia, 1910-64. Business History, 42, 3: 13-46.

Ville, S. and D. T. Merrett (2006a) A time series for business profitability in twentiethcentury Australia, Australian Economic Review, 39, 3: 330-9.

Ville, S. and Merrett, D. T. (2006b) Investing in interorganisational communication: the Melbourne Wool Brokers Association. In S. Ville, S. Macintyre and G. Boyce, eds. How Organizations Connect: Investing in Communication (Melbourne: Melbourne University Press), pp. 171-97.

Ville, S. and Merrett, D. T. (2016) Too big to fail: explaining the timing and nature of intervention in the Australian wool market, 1916-1991. Australian Journal of Politics and History, 62, 3: 335-350.

Wright, W. (2017) Occupying the interdisciplinary space: a visualisation of Australia's economic history field, 1950 - 1991. PhD thesis, University of Wollongong. 
